\title{
Chemical composition, antioxidant and anti-inflammatory activities of the essential oils from male and female specimens of Baccharis punctulata
}

\section{(Asteraceae)}

\author{
Jociani Ascari $^{\mathrm{a}, *}$, Murilo Silva de Oliveira ${ }^{\mathrm{a}}$, Domingos Sávio Nunes ${ }^{\mathrm{b}}$, Daniel Granato ${ }^{\mathrm{b}}$, \\ Dilamara Riva Scharf ${ }^{\mathrm{c}}$, Edésio Simionatto ${ }^{\mathrm{c}}$, Michel Otuki ${ }^{\mathrm{d}}$, Bruna Soley ${ }^{\mathrm{d}}$, Gustavo Heiden ${ }^{\mathrm{e}}$ \\ ${ }^{a}$ Universidade Tecnológica Federal do Paraná, Prolongamento da Rua Cerejeira, s/n, CEP 85892-000 Bairro São Luiz - Santa Helena, PR, Brazil \\ ${ }^{\mathrm{b}}$ Universidade Estadual de Ponta Grossa, Avenida Carlos Cavalcanti 4748, CEP: 84030-900 Ponta Grossa, PR, Brazil \\ ${ }^{\mathrm{c}}$ Universidade Regional de Blumenau, Campus II/Bloco I - Sala 007. Rua São Paulo, 3250, CEP: 89030-000 Blumenau, SC, Brazil \\ ${ }^{\mathrm{d}}$ Universidade Federal do Paraná, Politécnico - Anexo da Farmacologia Sala 102, Avenida Coronel Francisco H. dos Santos, s/n, Bairro: Jardim das Américas, CEP: \\ 81530-900 Curitiba, PR, Brazil \\ e Embrapa Clima Temperado, Rodovia BR 392, km 78. Caixa Postal 403, CEP: 96010-971 Pelotas, RS, Brazil
}

\section{A R T I C L E I N F O}

\section{Keywords:}

Baccharis punctulata

Essential oil

Topical anti-inflammatory

\begin{abstract}
A B S T R A C T
Ethnopharmacological relevance: Baccharis punctulata (Asteraceae), popularly known as "Chíllka saru saru" in Bolivia, has been used by rural communities in Bustillo Province of the Potosi Department for treatment of asthma, luxations and contusions.

Aim of the study: To analyze the chemical composition of the essential oils obtained from leaves of female (BPF) and male (BPM) specimens and evaluate their anti-inflammatory and antioxidant properties.

Material and methods: Chemical composition analyses of Baccharis punctulata essential oils isolated by hidrodistillation from leaves of male and female specimens were performed by GC-FID-MS. The in vivo anti-inflammatory activity was evaluated using the model of TPA (12-O-tetradecanoylphorbol-13-acetate) induced ear edema, and the polymorphonuclear cell migration was evaluated by mieloperoxidase (MPO) and analyzed histologically. To measure the reactive oxygen species (ROS) in the inflamed tissue, the DCFH-DA fluorescent probe was used. The chemical in vitro antioxidant activity of essential oils was determined using the 2,2-diphenyl-1-picryl-hydrazyl (DPPH) free radical assay.

Results: The chemical analysis showed high proportion of sesquiterpenes in the volatiles samples obtained from BPM, such as $\delta$-elemene (14.29\%), germacrene D (11.29\%) and bicyclogermacrene (10.90\%), and in the sample from BPF, bicyclogermacrene (42.44\%), germacrene D (21.18\%) and $\beta$-caryophyllene (14.06\%). A statistical difference $(p<0.05$ ) on chemical composition between both essential oils was observed. Topical administration of both BPM and BPF essential oils was able to inhibit the formation of TPA-induced edema in the treated groups. Isolated administration of TPA promoted an increase in MPO enzyme activity, and inhibition of the increase of MPO activity was observed when animals were treated with BFP at concentrations of $0.1 \mathrm{mg} / \mathrm{ear}$ $(13.69 \pm 0.20 \%), 0.3 \mathrm{mg} /$ ear $(22.35 \pm 0.11 \%)$, and $1.0 \mathrm{mg} /$ ear $(44.98 \pm 0.27 \%)$. Topical treatment with BPM was able to inhibit MPO activity at $22.40 \pm 0.29 \%(0.1 \mathrm{mg} / \mathrm{ear}), 36.49 \pm 0.07 \%(0.3 \mathrm{mg} / \mathrm{ear})$ and $52.19 \pm 0.28 \%$ (1.0 mg/ear). The positive control of dexamethasone (DEXA, $0.1 \mathrm{mg} / \mathrm{ear}$ ) was able to revert the increase in the enzymatic activity of MPO caused by TPA (65.16\%). Histological analysis showed that topical application of TPA promoted intense cellular infiltration. This inflammatory parameter was reduced with the topical application of the BPF and BPM oil samples as well as with DEXA. The results observed in the ROS and DPPH tests suggest that both samples were able to reduce the inflammatory cells influx and have in vitro antioxidant properties, respectively.
\end{abstract}

Conclusions: This study presents, for the first time, the chemical composition of the essential oils obtained from

\footnotetext{
* Corresponding author.

E-mail addresses: jascari@utfpr.edu.br (J. Ascari), murilo_tinelli@hotmail.com (M.S. de Oliveira), senunsd@gmail.com (D.S. Nunes), granatod@gmail.com (D. Granato), dilaquim@gmail.com (D.R. Scharf), edesiofurb@gmail.com (E. Simionatto), michelotuki@yahoo.com.br (M. Otuki), brunasoley@gmail.com (B. Soley), gustavo.heiden@gmail.com (G. Heiden).
} 
leaves of male and female specimens of Baccharis punctulata, and their anti-inflammatory and antioxidant activities. The results presented by the volatile samples in our biotests support traditional uses of this plant species.

\section{Introduction}

Baccharis L. (Asteraceae) includes approximately 400 species distributed in the Americas, mostly in Argentina, Colombia, Chile, Mexico and Brazil. Baccharis species are perennial shrubs from $50 \mathrm{~cm}$ to $4 \mathrm{~m}$ in height consisting of dioecious or rarely monoic plants (Giuliano, 2001; Heiden and Pirani, 2016; Nesom and Robinson, 2006). They are widely used in South America not only in traditional medicine but also because of their economical and environmental importance (Verdi, Brighente and Pizzolatti, 2005; Campos et al., 2016).

Baccharis punctulata DC., also known as "chilka saru saru", is traditionally used by rural communities in Bustillo Province of the Potosi Department, Bolivia, to treat asthma, dislocations and bruises. The administration is made using the infused green parts of the plant for asthma and in the form of poultice for luxations and contusions (Fernandez et al., 2003).

From the chemical standpoint, essential oils from the aerial parts of Baccharis species are mainly composed of terpenoids. However, few essential oils have commercial importance (Verdi, Brighente and Pizzolatti, 2005; Campos et al., 2016). High concentrations of monoterpenes and sesquiterpenes were already described in the essential oils obtained from this species (Ascari et al., 2012; Besten et al., 2012, 2014; Campos et al., 2016). Antimicrobial (Galvão et al., 2012), insect repellent (Gleiser et al., 2011), insecticide (Sosa et al., 2012), antiulcerogenic (Massignani et al., 2009), cytotoxic (Zapata et al., 2010), anti-inflammatory (Florão et al., 2012), and sedative (Ascari et al., 2012) properties of the essential oils have already been described.

Only few studies confirm the use of Baccharis species in traditional medicine by demonstrating pharmacological activities of extracts containing bioactive compounds. However, the use of essential oils obtained from Baccharis species has not been reported so far. Accordingly, Ascari et al. (2012) have demonstrated that the essential oil of $B$. uncinella DC. presents sedative properties, corroborating its traditional use by the Laklaño Indians in Ibirama, Santa Catarina, Brazil.

Chronic inflammatory skin diseases (CISD), such as atopic dermatitis (eczema) and psoriasis, affect genetically prone children and adults, associating with external factors. CISD are very common and incurable diseases and have a considerable socioeconomic impact as they reduce the patient's quality of life and self-esteem (Teplitsky et al., 2008; Wittmann et al., 2014). Treatment options may be limited because of the ineffectiveness of some existing drugs in patients who do not respond to the existing treatment or those individuals that present deleterious side effects (Schakel et al., 2014). The use of plant-based extracts that display anti-inflammatory properties and present the ability to regulate the synthesis of lipids in the epidermis may be a possible alternative to conventional drug therapy (Balunas and Kinghorn, 2005; Dawid-Pać, 2013).

Clinical studies evaluated the anti-inflammatory activity of ointment containing the extract from Matricaria recutita L. flowers in the treatment of patients suffering from inflammatory dermatoses in the hands, forearms, and legs. The preparation had a comparable effect to hydrocortisone at $0.25 \%$ and higher than $0.75 \%$ fluocortine butyl ester and $5 \%$ bufexamac (non-steroidal synthetic anti-inflammatory drugs) (Blumenthal et al., 2000a). There are many others examples of the advantageous use of plant extracts with recognized anti-inflammatory activity. The roots of Althaea officinalis L. are used in the treatment of furunculosis, eczema, and dermatitis (Ulbricht et al., 2009). Avena sativa L. is a medicinal species used in small skin inflammations (such as sunburns) and also as an aid in the healing of small wounds (EMEA, 2008). Salvia officinalis L. leaves are used to relieve minor skin inflammations and bacterial skin infections (EMEA, 2009).

Considering the use in the Bolivian traditional medicine and the limited scientific information on Baccharis punctulata, the objective of this study is to analyze the chemical composition of the essential oils from the leaves of male and female specimens, as well as their antioxidant properties in vitro and their in vivo anti-inflammatory activity.

\section{Material and methods}

\subsection{Chemicals}

Dexamethasone (DEXA), 12-O-tetradecanoylphorbol-acetate (TPA), hexadecyl-trimethylammonium bromide (HTAB), tetramethylbenzidine (TMB) all from Sigma Chemcil Co (St Louis MO); acetone, propanone, formaldehyde, glacial acetic acid, paraffin, dimethylformamide, phosphate-buffered (PBS) 2',7'-dichlorodihydrofluorescein diacetate (DCHFDA), 2,2-diphenyl-1-picrylhydrazyl radical (DPPH), ascorbic acid were purchased from Merck Biosciences (Germany); hydrogen peroxide, sodium acetate, ethanol, hematoxylin, and eosin were purchased from Vetec (Rio de Janeiro, Brazil). The other chemical reagents of analytical grade were purchased from local chemical suppliers.

\subsection{Plant material}

Leaves from male and female specimens of $B$. punctulata were collected in February 2017, in the city of Santa Helena in the West of the State of Paraná, Brazil, $24^{\circ} 48^{\prime} 15^{\prime \prime}$ South and $54^{\circ} 15^{\prime} 16^{\prime \prime}$ West, at an altitude of $368 \mathrm{~m}$. Exsicates were deposited under the numbers ECT0003425 (male) and ECT0003431 (female) in the ECT Herbarium from Embrapa Clima Temperado, Pelotas, State of Rio Grande do Sul, Brazil.

\subsection{Essential oils extraction and analysis}

The plant materials were dried at room temperature for 4 days and approximately $100 \mathrm{~g}$ of leaves of each specimen were hydrodistilled for $3 \mathrm{~h}$ using a Clevenger-type apparatus constructed according to the design and measures recommended in the literature (Stalh and Schild, 1981). The essential oils obtained were separated from the hydrolates using ethyl ether, the organic phases were dried with anhydrous $\mathrm{Na}_{2} \mathrm{SO}_{4}$, filtered and the solvent was evaporated under vacuum and at low temperature. The yields of the essential oil samples were calculated by considering the dry mass of each starting material.

The essential oils were analyzed on a Shimadzu GCMS-QP2010 Plus Gas Chromatograph using a non-polar Rtx-5MS column (30 m x $0.25 \mathrm{~mm} \times 0.25 \mu \mathrm{m}$ ). The following analysis conditions were used: split ratio of $1 / 20,250{ }^{\circ} \mathrm{C}$ for the injector, $250{ }^{\circ} \mathrm{C}$ for the ion source and $280^{\circ} \mathrm{C}$ for the interface. The oven temperature was programmed to $60{ }^{\circ} \mathrm{C}$ for the first $5 \mathrm{~min}$, increasing at a rate of $3{ }^{\circ} \mathrm{C} / \mathrm{min}$ to reach the final temperature of $240^{\circ} \mathrm{C}$. The components were identified based on the comparison of the relative retention indices calculated using a series of $n$-alkanes (C8-C19) and the mass spectra from the spectrometer database (NIST library), followed by comparison with the published data (Adams, 2009).

Quantitative analyses allowed the determination of the relative proportions of the components of the essential oils samples using a Shimadzu Gas 2010 Chromatograph with flame ionization detector (GC-FID) and a OV-5 column $(30 \mathrm{~m} \times 0.25 \mathrm{~mm} \times 0.25 \mu \mathrm{m})$. Helium was used as the carrier gas at a continuous flow rate of $1 \mathrm{~mL} / \mathrm{min}$, the split ratio of $1 / 20$, and the injection volume was $1 \mu \mathrm{L}$ of sample diluted 
in ethyl ether, with the detector at $280^{\circ} \mathrm{C}$, and the injector at $250^{\circ} \mathrm{C}$. The initial column temperature was adjusted to $60^{\circ} \mathrm{C}$ for $5 \mathrm{~min}$ and programmed for heating at a rate of $3{ }^{\circ} \mathrm{C} / \mathrm{min}$ until the final temperature reached $240{ }^{\circ} \mathrm{C}$.

\subsection{Animals}

Experiments were performed on female Swiss mice (25-30 g) randomly allocated in different groups ( $\mathrm{n}=6$ per group) The sample size of this experiment was established based on the formula $\mathrm{n}=[(2 . \mathrm{SD} 2)$. (E2) -1$]$. K, considering $\alpha=0.05$ and the power of the test was at 0.80 . Food and water were supplied ad libidum and kept in a $12 \mathrm{~h}$ light/ dark cycle and room temperature controlled $\left(22 \pm 2{ }^{\circ} \mathrm{C}\right)$. Animals were allowed to adapt to the laboratory for at least $1 \mathrm{~h}$ before testing and were used only once. The experiments were conducted in accordance with the ethical principles established by the Brazilian College of Animal Experimentation (COBEA) and approved by the Ethics Committee for the use of animals (CEUA) of the Universidade Federal do Paraná (protocol number: 1187).

\subsection{Anti-inflammatory assay}

\subsubsection{Ear acute inflammation by TPA}

Ear acute skin inflammation was induced topically by the administration of 12-O-tetradecanoylphorbol-13-acetate (TPA) $(2.0 \mathrm{mg} / \mathrm{ear})$ on right ear. Essential oil of especimens male (BPM) and female (BPF) $(0.1 ; 0.3$ and $1.0 \mathrm{mg} /$ ear) and dexamethasone (DEXA) $(0.1 \mathrm{mg} /$ ear) were applied immediately following TPA. The solutions were diluted in acetone. Ear thickness was measured before and $6 \mathrm{~h}$ after TPA-induced inflammation with a digital micrometer (Great, MT-04513). After $24 \mathrm{~h}$, animals were euthanized and ear biopsies $(6 \mathrm{~mm})$ collected and submitted to further analysis (Otuki et al., 2005).

\subsubsection{MPO enzymatic activity assay}

The methodology of Bradley et al. (1982) modified by De Young et al. (1989) was used to assess myeloperoxidase activity (MPO). Ear biopsies $(6 \mathrm{~mm})$ were added to $0.75 \mathrm{~mL}$ of $80 \mathrm{mmol} / \mathrm{L}$ PBS pH 5.4 containing $0.5 \%$ of $\mathrm{HTAB}$ and homogenized. The homogenate was decanted into microtubes and added to $0.75 \mathrm{~mL}$ of PBS. Samples $(1.5 \mathrm{~mL})$ were placed in microfuge tubes and centrifuged at $11.200 \mathrm{~g}$ at $4{ }^{\circ} \mathrm{C}$ for $20 \mathrm{~min}$. MPO activity was measured in triplicate. Briefly, $30 \mu \mathrm{L}$ of the supernatant were placed on 96-well plates together with $200 \mu \mathrm{L}$ of a mixture containing $100 \mu \mathrm{L}$ of $80 \mathrm{mmol} / \mathrm{L}$ PBS pH 5.4, $85 \mu \mathrm{L}$ of $0.22 \mathrm{~mol} / \mathrm{L}$ PBS pH 5.4 and $15 \mu \mathrm{L}$ of $0.017 \%$ hydrogen peroxide. The addition of $20 \mu \mathrm{L}$ of $18.4 \mathrm{mmol} / \mathrm{L}$ TMB in dimethylformamide started the reaction. The plate was then incubated at $37^{\circ} \mathrm{C}$ for $3 \mathrm{~min}$ and the reaction was stopped by the addition of $30 \mu \mathrm{L}$ of $1.46 \mathrm{~mol} / \mathrm{L}$ sodium acetate at $\mathrm{pH}$ 3.0. The enzymatic activity was determined colourimetrically at $630 \mathrm{~nm}$ using a plate reader (EL808; BioTech Instruments, INC). The results were expressed as mOD/Biopsy.

\subsubsection{Histological analysis}

Ear samples $(6.0 \mathrm{~mm})$ were fixed in an ethanol $80 \%$, formalin $40 \%$, and glacial acetic acid solution (ALFAC solution). Subsequently, the samples were subjected to a serial dehydration, embedded in paraffin, sectioned into $5 \mu \mathrm{m}$ slices and stained with hematoxylin-eosin (HE). The evaluation of cellularity was performed from representative areas with a magnification of $400 \mathrm{x}$ and analyzed with the Image $J^{\circledR}$ software version 1.48 (National Institute of Health, USA).

\subsubsection{Evaluation of reactive oxygen species (ROS)}

Evaluation of intracellular ROS was conducted accordingly to Hempel et al. (1999) with slight modifications. Briefly, tissue samples were homogenized in $80 \mathrm{mmol} / \mathrm{L}$ of PBS (pH 7.2) for $45 \mathrm{~s}$ at $0{ }^{\circ} \mathrm{C}$. Homogenates were incubated with $2 \mathrm{mmol} / \mathrm{L}$ DCHF-DA for $40 \mathrm{~min}$ $\left(37^{\circ} \mathrm{C}\right)$. Conversion of DCHF-DA to fluorescent DCHF was assessed using a plate reader (EL808; BioTech Instruments, INC) $485 \mathrm{~nm}$ (excitation) and $530 \mathrm{~nm}$ (emission). The results were expressed as fluorescent unit.

\subsection{In vitro antioxidant assay}

The antioxidant activity of the BPM and BPF samples in relation to the 2,2-diphenyl-1-picrylhydrazyl radical (DPPH) were tested in triplicate using the experimental conditions adopted by Granato et al. (2015). For this purpose, the essential oil samples were diluted in propanone and the DPPH was prepared in ethyl alcohol at a concentration of $0.10 \mathrm{mmol} / \mathrm{L}$. In a microplate, $260 \mu \mathrm{L}$ of the DPPH solution were mixed with $40 \mu \mathrm{L}$ of the diluted samples and the reaction occurred in the dark for $30 \mathrm{~min}$. Propanone was used as a negative control of the assay and the results were compared with a standard curve of ascorbic acid (7.5-50 mg/L, $\left.\mathrm{R}^{2}=0.9975\right)$, and the results were expressed as $\mathrm{mg}$ of ascorbic acid equivalent per $\mathrm{g}$ of essential oil (AAE/g).

\subsection{Statistical analysis}

The results were expressed as mean \pm standard error of the mean (SEM). For the in vivo study, the statistical significance between the test groups was assessed by means of one-way analysis of variances (ANOVA) followed by the Fisher least significant difference post-hoc test according to the principles outlined by Granato et al. (2014). For the chemical composition analysis and in vitro antioxidant activity, both essential oils (male - BPM - and female - BPF - specimens) were compared using the unpaired Student-t-test. The accepted level of significance for the tests was $p<0.05$. All tests were carried out using the GraphPad Prism software version 6.0 (La Jolla, California, USA).

\section{Results}

\subsection{Chemical compositions of essentials oils}

The essential oils from the leaves of female and male specimens of $B$. punctulata presented yields of $1.62 \%$ and $0.87 \%(\mathrm{w} / \mathrm{w})$ based on dry weight, respectively, although both specimens were collected at full bloom time and growing a few meters apart. This result initially showed that the synthesis of volatile substances between male and female specimens from the same species is quite different.

The chemical compositions were analyzed by the GC-FID-MS technique and the results are presented in Table 1 . Were identified 45 compounds in the essential oil samples (27 in BPF and 18 in BPM) representing $96.32 \%$ and $74.65 \%$ of the respective essential oils. The BPF and BPM samples were characterized by the high concentration of nonoxygenated sesquiterpenes, $85.83 \%$ and $63.55 \%$, respectively.

As can be seen in Table 1, bicyclogermacrene (42.44\%) was present in the BPF sample as the major compound, followed by germacrene D (21.18\%) and $\beta$-caryophyllene (14.06\%), while in the BPM sample the major compounds were $\delta$-elemene $(14.29 \%)$, germacrene D $(11.29 \%)$, bicyclogermacrene $(10.90 \%), \beta$-farnesene $(6.74 \%)$ and $\beta$-elemene $(6.11 \%)$. The results of the chemical analyses of the BPF and BPM samples were statistically different $(\mathrm{p}<0.05)$ for oxygenated monoterpenes, sesquiterpenes hydrocarbons and oxygenated sesquiterpenes. Only the BPF sample showed monoterpene hydrocarbons $(4.48 \%)$, being limonene $(3.40 \%)$ and $\beta$-ocimene $(1.08 \%)$ as the identified chemical compounds.

\subsection{Effects of the essential oils in the skin inflammation induced by TPA}

The topical treatment with BPF and BPM (0.1, 0.3 and $1.0 \mathrm{mg} /$ ear) was able to reduce the formation of the edema TPA-induced. The reductions were equal to $25.37 \pm 5.32 \%$ ( $0.1 \mathrm{mg} /$ ear $), 43.13 \pm 13.87 \%$ $(0.3 \mathrm{mg} / \mathrm{ear})$ and $43.13 \pm 14.86 \%(1.0 \mathrm{mg} / \mathrm{ear})$ when the treatment 
Table 1

Relative composition (\%) of the identified components in the analyses of the essential oils from leaves of female $(Q)$ and male $\left(\sigma^{\top}\right)$ specimens of B. punctulata.

\begin{tabular}{|c|c|c|c|c|c|}
\hline Components & $\mathrm{RI}^{\mathrm{a}}$ & $\mathrm{RI}^{\mathrm{b}}$ & *BPF O & *BPM $\sigma^{\prime}$ & p-Value ${ }^{1}$ \\
\hline NI & 974 & - & $2.10 \pm 0.11$ & - & NA \\
\hline Limonene & 1026 & 1029 & $3.40 \pm 0.15$ & ND & NA \\
\hline$\beta$-Ocimene & 1046 & 1050 & $1.08 \pm 0.04$ & ND & NA \\
\hline Terpinen-4-ol & 1176 & 1177 & $0.13 \pm 0.00$ & $\mathrm{ND}$ & NA \\
\hline Bornyl acetate & 1285 & 1285 & $0.66 \pm 0.01$ & $0.59 \pm 0.01$ & $<0.001$ \\
\hline Safrole & 1287 & 1287 & $0.13 \pm 0.00$ & ND & NA \\
\hline$\delta$-Elemene & 1336 & 1338 & $1.97 \pm 0.01$ & $14.29 \pm 0.06$ & $<0.001$ \\
\hline $\mathrm{NI}$ & 1348 & - & $0.14 \pm 0.00$ & - & NA \\
\hline Copaene & 1374 & 1376 & $0.11 \pm 0.00$ & ND & NA \\
\hline NI & 1384 & - & - & $0.39 \pm 0.00$ & NA \\
\hline$\beta$-Cubebene & 1389 & 1388 & $0.21 \pm 0.00$ & ND & NA \\
\hline$\beta$-Elemene & 1391 & 1390 & $1.12 \pm 0.00$ & $6.11 \pm 0.02$ & $<0.001$ \\
\hline$\beta$-Caryophyllene & 1419 & 1419 & $14.06 \pm 0.07$ & $5.59 \pm 0.03$ & $<0.001$ \\
\hline$\beta$-Gurjunene & 1428 & 1433 & $0.13 \pm 0.00$ & $0.11 \pm 0.01$ & 0.003 \\
\hline$\gamma$-Elemene & 1433 & 1436 & $\mathrm{ND}$ & $0.69 \pm 0.00$ & NA \\
\hline Aromadendrene & 1438 & 1441 & $0.25 \pm 0.00$ & $\mathrm{ND}$ & NA \\
\hline$\alpha$-Humulene & 1453 & 1454 & $1.54 \pm 0.01$ & $0.27 \pm 0.00$ & $<0.001$ \\
\hline$\beta$-Farnesene & 1456 & 1456 & ND & $6.74 \pm 0.03$ & NA \\
\hline Allo-aromadendrene & 1460 & 1460 & $0.24 \pm 0.00$ & ND & NA \\
\hline NI & 1461 & - & - & $0.17 \pm 0.01$ & NA \\
\hline NI & 1472 & - & - & $0.22 \pm 0.00$ & NA \\
\hline NI & 1473 & - & $0.14 \pm 0.01$ & - & NA \\
\hline $\mathrm{NI}$ & 1476 & - & - & $0.37 \pm 0.00$ & NA \\
\hline$\gamma$-Muurolene & 1477 & 1479 & $0.14 \pm 0.03$ & ND & NA \\
\hline Germacrene D & 1482 & 1481 & $21.18 \pm 0.16$ & $11.29 \pm 0.04$ & $<0.001$ \\
\hline Valencene & 1491 & 1496 & $0.30 \pm 0.01$ & $0.37 \pm 0.00$ & $<0.001$ \\
\hline Bicyclogermacrene & 1499 & 1494 & $42.44 \pm 0.10$ & $10.90 \pm 0.05$ & $<0.001$ \\
\hline$\alpha$-Selinene & 1505 & 1498 & $0.41 \pm 0.01$ & ND & NA \\
\hline NI & 1507 & - & - & $0.27 \pm 0.00$ & NA \\
\hline $\begin{array}{l}\text { Butyllated } \\
\text { hydroxytoluene }\end{array}$ & 1512 & 1515 & $0.12 \pm 0.00$ & $4.31 \pm 0.03$ & $<0.001$ \\
\hline NI & 1518 & - & - & $0.26 \pm 0.00$ & NA \\
\hline$\delta$-Cadinene & 1523 & 1523 & $1.77 \pm 0.01$ & $4.46 \pm 0.03$ & $<0.001$ \\
\hline NI & 1532 & - & - & $0.35 \pm 0.00$ & NA \\
\hline NI & 1538 & - & - & $0.28 \pm 0.00$ & NA \\
\hline NI & 1542 & - & - & $0.9 \pm 0.01$ & NA \\
\hline Elemol & 1549 & 1549 & $0.30 \pm 0.01$ & $1.28 \pm 0.01$ & $<0.001$ \\
\hline NI & 1552 & - & - & $0.67 \pm 0.01$ & NA \\
\hline Germacrene B & 1557 & 1561 & $\mathrm{ND}$ & $2.73 \pm 0.02$ & NA \\
\hline (E)-Nerolidol & 1562 & 1563 & $1.52 \pm 0.01$ & ND & NA \\
\hline NI & 1567 & - & $0.24 \pm 0.00$ & - & NA \\
\hline NI & 1572 & - & $0.53 \pm 0.01$ & $0.17 \pm 0.00$ & $<0.001$ \\
\hline NI & 1575 & - & - & $0.15 \pm 0.00$ & NA \\
\hline Spathulenol & 1578 & 1578 & $0.23 \pm 0.00$ & $0.60 \pm 0.01$ & $<0.001$ \\
\hline Caryophyllene oxide & 1580 & 1583 & ND & $0.19 \pm 0.01$ & NA \\
\hline NI & 1588 & - & $0.14 \pm 0.01$ & - & NA \\
\hline NI & 1599 & - & - & $0.17 \pm 0.01$ & NA \\
\hline NI & 1603 & - & - & $3.34 \pm 0.08$ & NA \\
\hline NI & 1607 & - & - & $0.48 \pm 0.01$ & NA \\
\hline NI & 1612 & - & - & $1.08 \pm 0.02$ & NA \\
\hline NI & 1621 & - & - & $1.21 \pm 0.03$ & NA \\
\hline NI & 1626 & - & - & $0.15 \pm 0.00$ & NA \\
\hline NI & 1628 & - & $0.18 \pm 0.00$ & - & NA \\
\hline NI & 1634 & - & - & $0.61 \pm 0.02$ & NA \\
\hline NI & 1639 & - & - & $0.71 \pm 0.02$ & NA \\
\hline$\tau$-Cadinol & 1642 & 1640 & $0.24 \pm 0.00$ & ND & NA \\
\hline NI & 1643 & - & - & $1.27 \pm 0.03$ & NA \\
\hline Torreyol & 1647 & 1646 & $0.64 \pm 0.01$ & $4.13 \pm 0.08$ & $<0.001$ \\
\hline$\alpha$-Cadinol & 1655 & 1654 & $0.95 \pm 0.02$ & ND & NA \\
\hline NI & 1660 & - & - & $0.43 \pm 0.01$ & NA \\
\hline NI & 1664 & - & - & $1.17 \pm 0.03$ & NA \\
\hline NI & 1670 & - & - & $0.22 \pm 0.01$ & NA \\
\hline NI & 1675 & - & $0.16 \pm 0.00$ & - & NA \\
\hline NI & 1676 & - & - & $0.58 \pm 0.01$ & NA \\
\hline NI & 1685 & - & - & $0.41 \pm 0.01$ & NA \\
\hline NI & 1700 & - & - & $1.18 \pm 0.07$ & NA \\
\hline NI & 1704 & - & - & $0.32 \pm 0.02$ & NA \\
\hline NI & 1750 & - & - & $0.6 \pm 0.03$ & NA \\
\hline NI & 1768 & - & - & $0.24 \pm 0.02$ & NA \\
\hline Total identified (\%) & & & 96.32 & 74.65 & NA \\
\hline NI & & & $3.63 \pm 0.14$ & $18.37 \pm 0.46$ & NA \\
\hline
\end{tabular}

Table 1 (continued)

\begin{tabular}{|c|c|c|c|c|c|}
\hline Components & $\mathrm{RI}^{\mathrm{a}}$ & $\mathrm{RI}^{\mathrm{b}}$ & *BPF & *BPM $\sigma^{*}$ & p-Value ${ }^{1}$ \\
\hline $\begin{array}{l}\text { Monoterpene } \\
\text { hydrocarbons } \\
(\%)\end{array}$ & & & $4.48 \pm 0.19$ & 0 & NA \\
\hline $\begin{array}{l}\text { Oxygenated } \\
\text { monoterpenes } \\
(\%)\end{array}$ & & & $0.92 \pm 0.01$ & $0.59 \pm 0.01$ & $<0.001$ \\
\hline $\begin{array}{l}\text { Sesquiterpene } \\
\text { hydrocarbons } \\
(\%)\end{array}$ & & & $85.83 \pm 0.38$ & $63.55 \pm 0.29$ & $<0.001$ \\
\hline $\begin{array}{l}\text { Oxygenated } \\
\text { sesquiterpenes } \\
\text { (\%) }\end{array}$ & & & $4.00 \pm 0.05$ & $10.51 \pm 0.14$ & $<0.001$ \\
\hline $\begin{array}{l}\text { Sample yielding (w/ } \\
\text { w) (\%) }\end{array}$ & & & 1.62 & 0.87 & NA \\
\hline
\end{tabular}

$\mathrm{RI}^{\mathrm{a}}$ : values of calculated relative retention indices using the column RTX-5 (GCMS) and the n-alkanes series $\mathrm{C}_{8}-\mathrm{C}_{19}$. $\mathrm{RI}^{\mathrm{b}}$ : published relative retention indices for the a polar column DB- $5^{1}$; ND: not detected or $<0.10 \%$, NI: not identified; NA: not applicable. *: means of calculated relative compositions using the column OV-5 (GC-FID) and the n-alkanes series $\mathrm{C}_{8}-\mathrm{C}_{19}$. ${ }^{1}$ Probability values obtained by the unpaired Student-t-test.
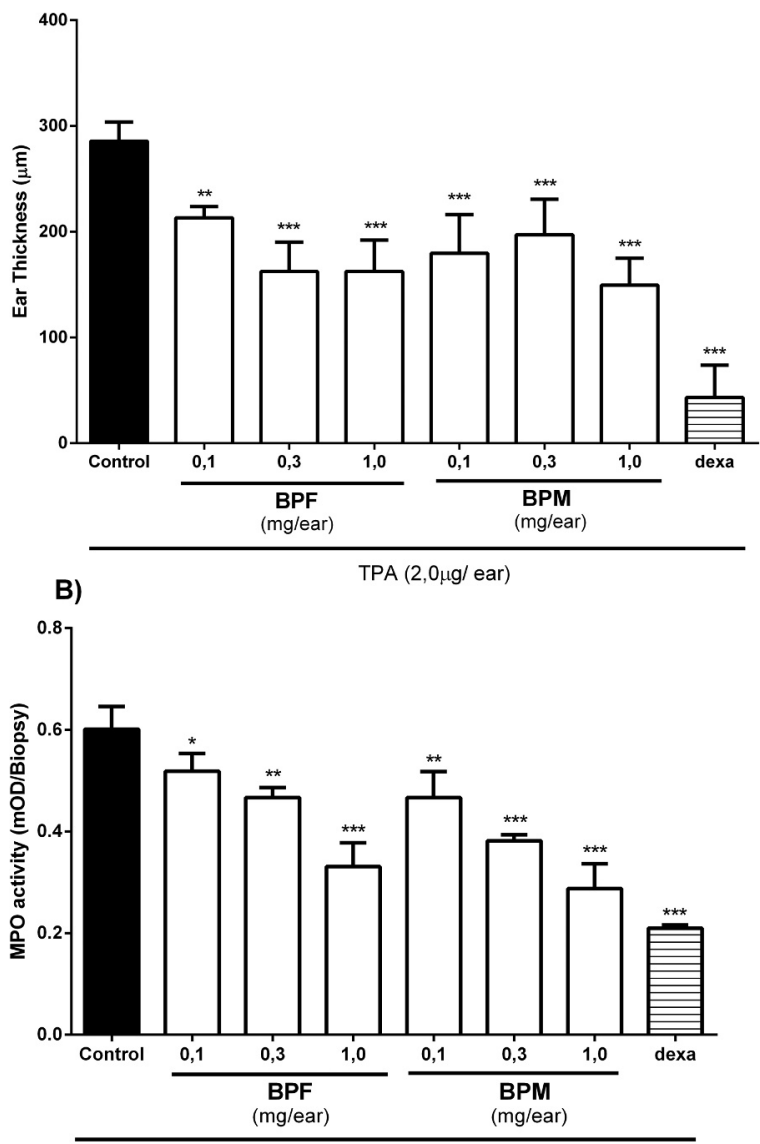

TPA $(2,0 \mu \mathrm{g} /$ ear $)$

Fig. 1. Topical effect of essential oils BPF and BPM in skin acute inflammation induced by the TPA application (A) and MPO activity in homogenates from TPA-treated ears (B). The bars represent the mean \pm SEM, $(n=5-6$ animals). $* * * \mathrm{p}<0.001, * * \mathrm{p}<0.01$ and $* \mathrm{p}<0.05$ compared with the control.

was with BPF. Similarly, the topical application of BPM reduced $37.09 \pm 18.25 \%$ (0.1 mg/ear), $30.97 \pm 16.75 \%$ (0.3 mg/ear) and $47.68 \pm 12.74 \%$ (1.0 mg/ear). The DEXA used as positive control, inhibited the formation of edema in $84.86 \pm 15.22 \%(0.1 \mathrm{mg} /$ ear $)$ (Fig. 1A). 


\subsection{Influence of the essential oils in the inflammatory cells migration}

The results showed that administration of the phlogistic agent promoted an increase in the activity of the MPO enzyme, as well as the inhibition of the increase of MPO enzyme activity when the animals received BPF treatment at concentrations of $0.1 \mathrm{mg} / \mathrm{ear}$ $(13.69 \pm 0.20 \%), \quad 0.3 \mathrm{mg} / \mathrm{ear} \quad(22.35 \pm 0.11 \%)$ and $1.0 \mathrm{mg} / \mathrm{ear}$ (44.98 $\pm 0.27 \%)$. Similarly, topical BPM treatment reduced the MPO activity by $22.40 \pm 0.29 \%(0.1 \mathrm{mg} /$ ear $), 36.49 \pm 0.07 \%(0.3 \mathrm{mg} /$ ear $)$ and $52.19 \pm 0.28 \%(1.0 \mathrm{mg} /$ ear $)$. DEXA $(0.1 \mathrm{mg} /$ ear $)$ reduced the MPO activity by $65.16 \pm 0.003$ (Fig. 1B). This result suggests that the treatment with BPF and BPM was able to reduce the number of leukocytes in the inflamed tissue.

To verify the influence of the BPF and BPM treatment in migration of inflammatory cells, the histological analysis was performed. The results showed that the TPA topical administration was able to promote increased of inflammatory cells influx, when compared to the naive group (did not receive the phlogistic agent administration) (Fig. 2). Similarly, the number of stained nuclei showed reduction in cellularity of $52.43 \pm 6.9 \%$ and $33.58 \pm 8.6 \%$ in the groups treated topically with the essential oils BPF and BPM $(1.0 \mathrm{mg} /$ ear), respectively, when compared to group control. In the same sense, DEXA $(0.1 \mathrm{mg} / \mathrm{ear})$ promoted a significant reduction of $68.31 \pm 4.39 \%$ when compared to the control group (TPA) (Fig. 2).

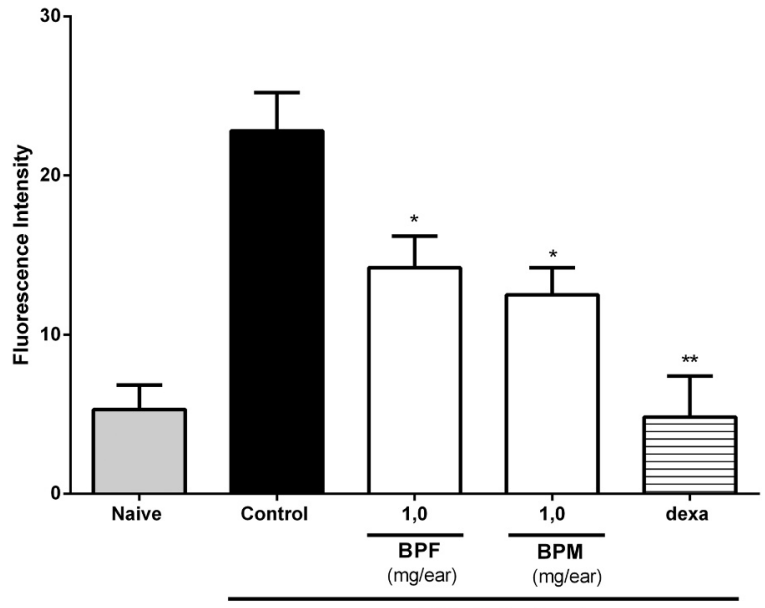

TPA $(2,0 \mu \mathrm{g} /$ ear $)$

Fig. 3. BPF and BPM effects in reactive oxygen species (ROS). The bars represent the mean \pm SEM, $\left(n=5-6\right.$ animals). ${ }^{* * *} \mathrm{p}<0.001, * * \mathrm{p}<0.01$ and ${ }^{*} \mathrm{p}<0.05$ compared to the control group.

\section{A)}

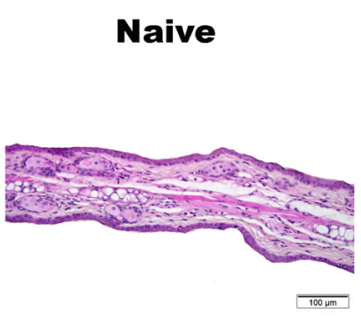

$7100 \mathrm{wm}$
BPF

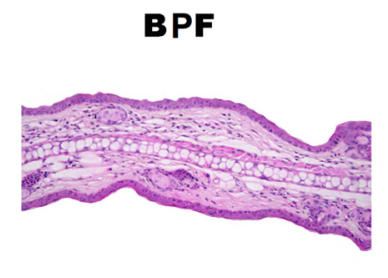

\section{Control}

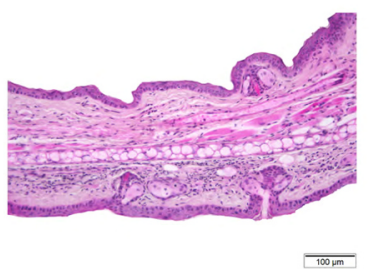

BPM

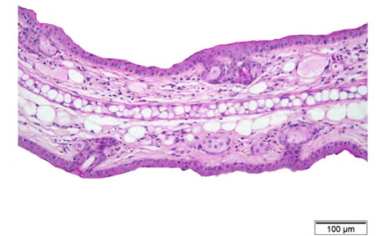

Dexa

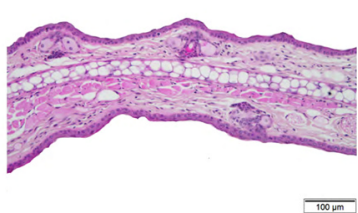

B)

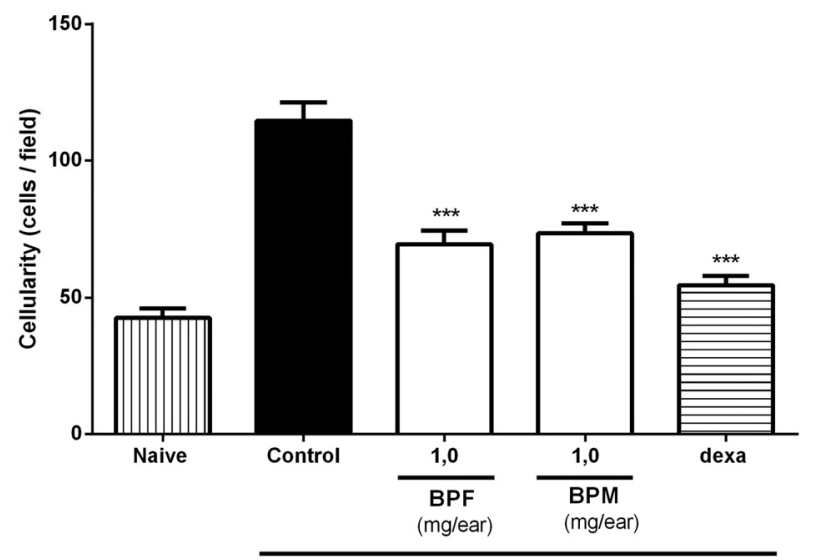

TPA (2,0 $\mathrm{pg} /$ ear)

Fig. 2. Representative images of ears cross-sections stained with hematoxylin/eosin (A) and count cells from histological sections (B). *** $\mathrm{p}<0.001,{ }^{* *} \mathrm{p}<0.01$ compared to the control group. 
To measure the reactive oxygen species (ROS) in the inflamed tissue, the DCFH-DA fluorescent probe was used (Fig. 3). The results showed that the TPA topical admininstration promoted increased in de ROS levels. While the topical treatment with BPM and BPF was able to reduce the ROS levels $(58.83 \pm 2.00 \%$ and $49.12 \pm 1.7 \%$, respectively) when compared with the control group (Fig. 3). The positive control (DEXA) reduced the ROS to basal levels.

The free radical scavenging activity of the BPF and BPM was determined using the DPPH assay and results are shown in Fig. 4. Data show that the BPM sample exhibited significantly higher $(\mathrm{p}=0.0002)$ antioxidant activity $(0.328 \mathrm{mg} \mathrm{AAE} / \mathrm{g})$ as compared to the sample BPF (0.182 mg AAE/g).

\section{Discussion and Conclusion}

In the present study we observed a lower proportion of monoterpenes compared to sesquiterpenes (Table 1). This trend was also observed in essential oils from leaves of several Baccharis species collected in other Brazilian geographic locations (Ascari et al., 2009; Mendes et al., 2008; Besten et al., 2012).

In a previous study, our group developed a detailed study on the main factors influencing the secondary metabolism of volatile organic compounds produced by female and male specimens of five Baccharis species. The specimens of each species were collected from populations growing in minute natural areas, which reduced or even eliminated the differences between volatile metabolite compositions because of environmental and genetic issues. The results from that research pointed out to the genetic and ecological factors as the most likely causes of differences in secondary metabolism between male and female specimens in this plant genus (Besten et al., 2012). The present research using $B$. punctulata as the target of investigation was developed based on this earlier field experience and results.

Taking into consideration that most of the Baccharis species are dioecious and can easily present differences on the volatile composition between male and female specimens, it is important to study both essential oils from the chemical and biological standpoints (Besten, 2012). By assessing and coparing the chemical and biological activities of essential oils from Baccharis punctulata specimens may shed light on their use and possible commercial exploitation as natural products. In this holistic view, one of the objectives of this work was to evaluate the anti-inflammatory activity of the essential oils from male and female specimens using the model of ear edema induced by topical application of TPA as a phlogistic agent (Murakawa et al., 2006). This model is an important method for the investigation of new anti-inflammatory drugs that affect the skin.

TPA-induced ear edema is a model used to evaluate the inflammatory response, since this phlogistic agent induces skin inflammation and cellular hyperproliferation (when applied in a chronic way) in animals, similar to several skin diseases, such as psoriasis (Gabor, 2003). The TPA when applied to the skin causes a rapid and potent irritant effect by activating the protein kinase C (PKC) pathway, which results in elevated levels of arachidonic acid prostaglandins and leukotrienes. In addition to promoting activation of the pathway of MAPKs, which promote the release of pro-inflammatory cytokines such as IL-1, TNF- $\alpha$, IL- 8 and MIP-1 $\beta$, adhesion molecules and enzymes, which result in the formation of edema and migration of leukocytes into the dermis are activated (Gabor, 2003; Calixto et al., 2004; Murakawa et al., 2006). In this model, the topical treatment with BPF and BPM were able to reverse the edema formation, suggesting topical antidematogenic activity of the evaluated compounds (Fig. 1).

The inflammatory cells influx was also evaluated was and the obtained results showed that the treatment with BPF and BPM was able to reduce the myeloperoxidase activity. These data show that the BPF and $\mathrm{BPM}$ reduced the polymorphonuclear migration to the inflamed tissue. Corroborating these results, the histological analysis showed a lower number of inflammatory cells in the tissue samples treated with BPF and BPM as compared to the negative control. In addition, a significant reduction of the ROS levels was observed a in the groups treated with BPF and BPM.

There are several studies in the literature showing that neutrophils play an important role in the defense of the host, mainly for the ability to perform phagocytosis and generate ROS to eliminate a possible aggressor agent (Bradley et al., 1982; Schakel et al., 2014; Wittmann et al., 2014). Moreover, in acute inflammation models, neutrophils are the main cells responsible for the ROS production. In the current study, the treatment with BPF and BPM reduced the inflammatory cells influx, thus ROS the reduction may be associated with a reduction in the number of producing cells in the inflamed tissue. These results corroborate the DPPH test, that showed significant activity compared to the ascorbic acid control, suggesting that essential oil both specimens possessing antioxidant property.

$\beta$-Caryophyllene and $\alpha$-humulene are known to display anti-inflammatory activity in several models (Fernandes et al., 2007). Both compounds were found to be responsible for the pronounced in vivo anti-inflammatory properties of the essential oil from the leaves of Cordia verbenacea (Passos et al., 2007). In another study, the essential oil from Myrciaria tenella leaves showed potent anti-inflammatory activity, which was associated with $\beta$-caryophyllene present in the essential oil. In addition, $\beta$-caryophyllene in the isolated form influences the inhibition of nitric oxide (NO) and prostaglandin E (PGE) production in lipopolysaccharide (LPS)-activated RAW 264.7 macrophages (Apel et al., 2010; Tung et al., 2008).

The essential oil from Psidium guineense Sw. contains slightly more than $80 \%$ of spathulenol, with both crude oil and isolated substance exhibiting a certain anti-inflammatory and antioxidant activities, with significant inhibition of the carrageenan-induced paw edema and in the pleurisy model, as well as being effective against a cell line of ovarian cancer (Nascimento et al., 2018).

Bicyclogermacrene is one of the major compounds found in essential oils obtained from the leaves of Croton argyrophyllus Kunth and Casearia sylvestris Sw. (14.60\% and 40\%, respectively). Both oils demonstrated significant anti-inflammatory activity when tested in in vivo inflammatory models (Esteves et al., 2005; Ramos et al., 2013). However, as bicyclogermacrene was not isolated for the biological test, it seems very possible that the observed anti-inflammatory activity is partially associated to other components present in lower proportions, such as $\beta$ caryophyllene, which has been shown to be active in several pharmacological models. Future in vitro and in vivo studies should focus their attention to the effects of isolated compounds from essential oils on several pharmacological properties.

The essential oil from Chamaecyparis obtusa is mainly composed of sabinene and elemol. This oil showed anti-inflammatory effects regulating the production of PGE2 enzyme in the blood and the gene expression of TNF- $\alpha$ in rats. Such effects are mediated by the inhibition of the expression of the inflammation-specific COX-2 enzyme (An et al., 2013). Another study analyzed the anti-inflammatory atopic activity of

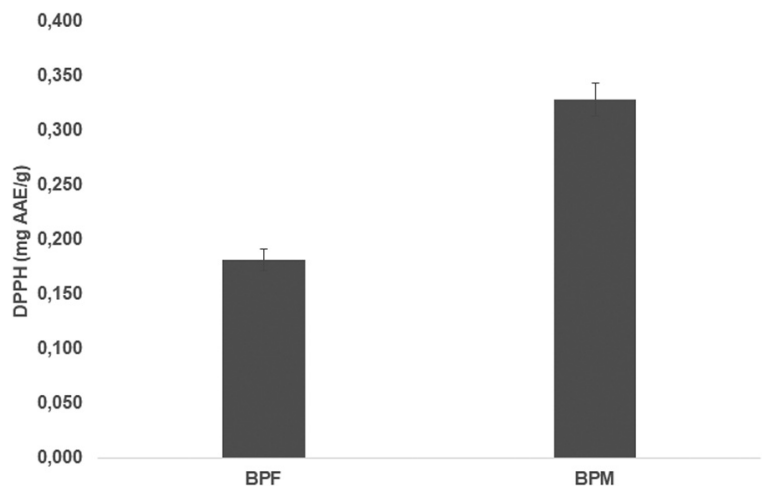

Fig. 4. Antoxidant activity of essential oils measured by the DPPH assay. 
elemol isolated from the essential oil of Chamaecyparis obtusa. Results showed that the essential oil presented potent anti-allergenic activity, particularly in models of atopic dermatitis or eczema, that is a chronic inflammatory skin disease affecting $10-20 \%$ of children and $1-3 \%$ of adults worldwide (Yang et al., 2015).

The anti-inflammatory activity of several isolated volatile organic compounds has been evaluated in models of induced edema. For instance, $\beta$-elemene (sesquiterpene) is the main constituent of the shells of Delonix regia which is traditionally used in the treatment of inflammatory diseases. According to Patra et al. (2016), $\beta$-elemene restricts inflammation in mice, and this effect is related to deregulation of the expression of proinflammatory cytokines, including iNOS, COX-2, TNF- $\alpha$, IL- 6 and IL- $1 \beta$, its upstream molecules, and the suppression of the TLR4/MyD88 signaling pathway.

Considering the volatile organic composition described above, our results suggest that the antioxidant and anti-inflammatory activities observed may be associated. In conclusion, the data presented in this study showed, for the first time in the literature, the chemical composition of female and male specimens of $B$. punctulata and their antioxidant and anti-inflammatory properties using different models.

\section{Acknowledgements}

The authors are grateful to $\mathrm{CNPq}$ (Conselho Nacional de Desenvolvimento Científico e Tecnológico, Brazil) D. Granato, 303188/ 2016-2; D.S. Nunes, 307329/2013-5 and Fundação Araucária, Brazil, for fellowships share UTFPR.

\section{Conflicts of interest}

No competing financial interests exist.

\section{References}

Adams, R.P., 2009. Identification of Essential Oil Components by Gas Chromatography/Mass Spectroscopy, 4th. Allured Publishing Corporation, Carol Stream, Illinois, USA.

An, B., Kang, J., Yang, H., Jung, E., Kang, H., Choi, I., Park, M., Jeung, E., 2013. Anti-inflammatory effects of essential oils from Chamaecyparis obtusa via the cyclooxygenase-2 pathway in rats. Mol. Med. Rep. 8, 255-259.

Apel, M., Lima, M.E.L., Sobral, M., Young, M.C.C., Cordeiro, I., Schapoval, E.E.S., Henriques, A.T., Moreno, P.R.H., 2010. Anti-inflammatory activity of essential oil from leaves of Myciaria tenella and Calycorectes sellowianus. Pharm. Biol. 48, 433-438.

Ascari, J., Nunes, D.S., Marques, M.B., Tardivo, R.C., Cechinel-Filho, V., Simionatto, E.L., Wisniewski Jr., A., 2009. Essential oils of Baccharis uncinella DC. Publicatio UEPG - Ciências Exatas e da Terra. Agrar. e Eng. 15, 73-77.

Ascari, J., Sens, S.L., Nunes, D.S., Wisniewski Jr., A., Arbo, M.D., Linck, V.M., Lunardi, P., Leal, M.B., Elisabetsky, E., 2012. Sedative effects of essential oils obtained from Baccharis uncinella. Pharm. Biol. 50, 113-119.

Balunas, M.J., Kinghorn, A.D., 2005. Drug discovery from medicinal plants. Life Sci. 78, $431-441$.

Besten, M.A., Jasinski, V.C.G., Costa, A.G.L.C., Nunes, D.S., Sens, S.L., Wisniewski Jr., A., Simionatto, E.L., Riva, D., Dalmarco, J.B., Granato, D., 2012. Chemical composition similarity between the essential oils isolated from male and female specimens of each five Baccharis species. J. Braz Chem. Soc. 23, 1041-1047.

Besten, M.A., Nunes, D.S., Wisniewski Jr., A., Sens, S.L., Granato, D., Simionatto, E.L., RivaScharf, D., 2014. Chemical composition of essential oils from cladodes and inflorescences from male and female specimens of Baccharis milleflora. J. Essent. Oil Bear. Plants 17, 889-905.

Blumenthal, M., Goldberg, A., Brinckann, J., 2000a. Herbal Medicine. Expanded Commission and Monographs. Chamomile flower, German. American Botanical Council, Newton, pp. $57-61$.

Bradley, P.P., Priebat, D.A., Christensen, R.D., Rothstein, G., 1982. Measurement of cutaneous inflammation: estimation of neutrophil content with an enzyme marker. J. Investig. Dermatol. 78, 206-209.

Calixto, J.B., Campos, M.M., Otuki, M.F., Santos, A.R., 2004. Antiinflammatory compounds of plant origin. Part II: modulation of proinflammatory cytokines, chemokines and adhesion molecules. Planta Med. 70, 93-103.

Campos, F.R., Bressan, J., Jasinski, V.C.G., Zuccolotto, T., da Silva, L.E., Cerqueira, L.B., 2016. Baccharis (Asteraceae): chemical constituents and biological activities. Chem. Biodivers. 13, 1-17.

Dawid-Pać, R., 2013. Medicinal plants used in treatment of inflammatory skin diseases. Post. Derm. Alergol. 30, 170-177.

De Young, L.M., Kheifets, J.B., Ballaron, S.J., Young, J.M., 1989. Edema and cell infiltration in the phorbol ester-treated mouse ear are temporally separate and can be differentially modulated by pharmacologic agents. Agents Actions 26, 335-341.

EMEA, 2008. European Medicines Agency. Avena sativa L. Herba and Avena sativa L., Fructus, London.
EMEA, 2009. European Medicines Agency. Salvia officinalis L. Folium and Salvia officinalis L., Aetheroleum, London.

Esteves, I., Souza, I.R., Rodrigues, M., Cardoso, L.G.V., Santos, L.S., Sertie, J.A.A., Perazzo, F.F., Lima, L.M., Schneedorf, J.M., Bastos, J.K., Carvalho, J.C.T., 2005. Gastric antiulcer and anti-inflammatory activities of the essential oil from Casearia sylvestris. Sw. J. Ethnopharmacol. 101, 191-196.

Fernandes, E.S., Passos, G.F., Medeiros, R., Cunha, F.M., Ferreira, J., Campos, M.M., Pianowski, L.F., Calixto, J.B., 2007. Antiinflammatory effects of compounds alpha-humulene and (-)-trans-caryophyllene isolated from the essential oil of Cordia verbenacea. Eur. J. Pharmacol. 569, 228-236.

Fernandez, E.C., Sandi, Y.E., Kokoska, L., 2003. Ethnobotanical inventory of medicinal plants used in the Bustillo Province of the Potosi Department, Bolivia. Fitoterapia 74, 407-416.

Florão, A., Budel, J.M., Duarte, J.M., Marcondes, A., Rodrigues, R.A.F., Rodrigues, M.V.N., Santos, C.A.De.M., Wefort-Santos, A.M., 2012. Essential oil from Baccharis species (Asteraceae) have anti-inflammatory effects for human cells. J. Essent. Oil Res. 24 $561-570$.

Gabor, M. 2003. Models of acute inflammation in the ear. Methods Mol. Biol. 225, 129-137. Galvão, L.C., de, C., Furletti, V.F., Bersan, S.M.F., da Cunha, M.G., Ruiz, A.L.T.G., de Carvalho, J.E., Sartoratto, A., Rehder, V.L.G., Figueira, G.M., Duarte, M.C.T., Ikegaki, M., de Alencar, S.M., Rosalen, P.L., 2012. Antimicrobial activity of essential oils against Streptococcus mutans and their antiproliferative effects. Evid. Based Complement. Altern. Med. 1-12.

Giuliano, D.A., 2001. Clasificación infragenérica de las especies argentinas de Baccharis (Asteraceae, Astereae). Darwiniana 39, 131-154.

Gleiser, R.M., Bonino, M.A., Zygadlo, J.A., 2011. Repellence of essential oils of aromatic plants growing in Argentina against Aedes aegypti (Diptera: culicidae). Parasitol. Res. 108, 69-78.

Granato, D., Calado, V.M.A., Jarvis, Brasil, 2014. Observations on the use os statistical methods in food science and tecnology. Food Res. Int. 55, 137-149.

Granato, D., Koot, A., Schnitzler, E., van Ruth, S.M., 2015. Authentication of geographical origin and crop system of grape juices by phenolic compounds and antioxidant activity using chemometrics. J. Food Sci. 80, 584-593.

Heiden, G., Pirani, J.R., 2016. Novelties towards a phylogenetic classification of Baccharis (Asteraceae, Astereae). Phytotaxa 289, 285-290.

Hempel, S.L., Buettner, G.R., O'Malley, Y.Q., Wessels, D.A., Flaherty, D.M., 1999. Dihydrofluorescein diacetate is superior for detecting intracellular oxidants: comparison with $2^{\prime}, 7^{\prime}$-dichlorodihydrofluorescein diacetate, 5 (and 6)-carboxy-2',7'-dichlorodihydrofluorescein diacetate and dihydrorhodamine. Free Radic. Biol. Med. 27, 146-159.

Massignani, J.J., Lemos, M., Maistro, E.L., Schaphauser, H.P., Jorge, R.F., Souza, J.P.B., Bastos, J.K., Andrade, S.F., 2009. Antiulcerogenic activity of the essential oil of Baccharis dracunculifolia on different experimental models in rats. Phytother. Res. 23, 1355-1360.

Mendes, S., Nunes, D.S., Marques, M.B., Tardivo, R.C., Cechinel-Filho, V., Simionatto, E.L., Wisniewski Jr, A., 2008. Essential oil of Baccharis semiserrata, a source of spathulenol. Publicatio UEPG - Ciências Exatas e da Terra, Agrárias e Engenharias. 14, 241-245.

Murakawa, M., Yamaoka, K., Tanaka, Y., Fukuda, Y., 2006. Involvement of tumor necrosis factor (TNF)- $\alpha$ in phorbol ester 12-O-tetradecanoylphorbol-13-acetate (TPA)-induced skin edema in mice. Biochem. Pharmacol. 71, 331-336.

Nascimento, K.F., Moreira, F.M.F., Santos, J.A., Kassuyab, C.A.L., Croda, J.H.R., Cardoso, C.A.L., Vieira, M., do, C., Ruiz, A.L.T.G., Foglio, M.A., Carvalho, J.E., Formagio, A.S.N., 2018. Antioxidant, anti-inflammatory, antiproliferative and antimycobacterial activities of the essential oil of Psidium guineense Sw. and spathulenol. J. Ethnopharmacol. 210, 351-358.

Nesom, G., Robinson, H., 2006. Tribe Astereae Cass. In: Kadereit, J.W., Jeffrey, C. (Eds.), The Families and Genera of Vascular Plants, Vol. VIII - Flowering Plants: Eudicots: Asterales. Springer, Berlin, pp. 284-342.

Otuki, M.F., Vieira-Lima, F., Malheiros, A., Yunes, R.A., Calixto, J.B., 2005. Topical anti-inflammatory effects of the ether extract from Protium kleinii and $\alpha$-amyrin pentacyclic triterpene. Eur. J. Pharmacol. 507, 253-259.

Passos, G.F., Fernandes, E.S., Cunha, F.M., da, Ferreira, J., Pianowski, L.F., Campos, M.M., Calixto, J.B., 2007. Anti-inflammatory and anti-allergic properties of the essential oil and active compounds from Cordia verbenacea. J. Ethnopharmacol. 110, 323-333.

Patra, S., Muthuraman, M.S., Meenub, M., Priya, P., Pemaiah, B., 2016. Anti-inflammatory effects of royal poinciana through inhibition of toll-like receptor 4 signaling pathway. Int. Immunopharmacol. 34, 199-211.

Ramos, J.M.O., Santos, C.A., Santana, D.G., Santos, D.A., Alves, P.B., Thomazzi, S.M., 2013 Chemical constituents and potential anti-inflammatory activity of the essential oil from the leaves of Croton argyrophyllus. Rev. Bras. de Farmacogn. 23, 644-650.

Schakel, K., Dobel, T., Bosselmann, I., 2014. Future treatment options for atopic dermatitis small molecules and beyond. J. Dermatol. Sci. 73, 91-100.

Sosa, M.E., Lancelle, H.G., Tonn, C.E., Fe Andres, M., Gonzalez-Coloma, A., 2012. Insecticidal and nematicidal essential oils from Argentinean Eupatorium and Baccharis spp. Biochem. Syst. Ecol. 43, 132-138.

Stalh, E., Schild, W., 1981. Drogenanalyse II: inhaltsstoffe und Isolierungen. Gustav Fischer Verlag, Stuttgart. New York, pp. 461.

Teplitsky, V., Mumcuoglu, K.Y., Babai, I., Dalal, I., Cohen, R., Tanay, A., 2008. House dust mites on skin, clothes, and bedding of atopic dermatitis patients. Int. J. Dermatol. 47, 790-795.

Tung, Y.T., Chua, M.T., Wang, S.Y., Chang, S.T., 2008. Anti-inflammation activities of essential oil and its constituents from indigenous cinnamon (Cinnamomum osmophloeum) twigs. Bioresour. Technol. 99, 3908-3913.

Ulbricht, C., Basch, E., Ulbricht, C., Hammerness, P., Vora, M., 2009. Marshmallow (Althaea officinalis L.) Monograph. J. Herb. Pharmacother. 3, 71-81.

Verdi, L.G., Brighente, I.M.C., Pizzolatti, M.G., 2005. Gênero Baccharis (Asteraceae): aspectos quimicos, economicos e biológicos. Quim. Nova 28, 85-94.

Wittmann, M., McGonagle, D., Werfel, T., 2014. Cytokines as therapeutic targets in skin inflammation. Cytokine Growth Factor Rev. 25, 443-451.

Yang, H., Jung, E., Ahn, C., Lee, G., Lee, S., Kim, S., Choi, I., Park, M., Lee, S., Choi, D., Jeun, E. 2015. Elemol from Chamaecyparis obtusa ameliorates 2,4-dinitrochlorobenzene-induced atopic dermatites. Int. J. Mol. Med. 36, 463-472.

Zapata, B., Durán, C., Stashenko, E., Betancur-Galvis, L., Mesa-Arango, A.C., 2010. Actividad antimicótica y citotóxica de aceites esenciales de plantas de la familia Asteraceae. Rev. Ibero. Micol. 27, 101-103. 